\title{
Lactate Dehydrogenase A is a potential prognostic marker in clear cell renal cell carcinoma
}

\author{
Hala Girgis ${ }^{1,2}$, Olena Masui ${ }^{3}$, Nicole MA White ${ }^{1,2,4}$, Andreas Scorilas ${ }^{5}$, Fabio Rotondo ${ }^{1,2}$, Annetta Seivwright ${ }^{1,2}$, \\ Manal Gabril ${ }^{6}$, Emily R Filter ${ }^{6}$, Andrew HA Girgis ${ }^{1,2}$, Georg A Bjarnason ${ }^{7}$, Michael AS Jewett ${ }^{8}$, Andrew Evans ${ }^{4,9}$, \\ Sahar Al-Haddad ${ }^{1,2,4}$, KW Michael Siü ${ }^{3}$ and George M Yousef ${ }^{1,2,4^{*}}$
}

\begin{abstract}
Background: Over 90\% of cancer-related deaths in clear cell renal cell carcinoma (RCC) are caused by tumor relapse and metastasis. Thus, there is an urgent need for new molecular markers that can potentiate the efficacy of the current clinical-based models of prognosis assessment. The objective of this study is to evaluate the potential significance of lactate dehydrogenase A (LDHA), assessed by immunohistochemical staining, as a prognostic marker in clear cell renal cell carcinoma in relation to clinicopathological features and clinical outcome.

Methods: We assessed the expression of LDHA at the protein level, by immunohistochemistry, and correlated its expression with multiple clinicopathological features including tumor size, clinical stage, histological grade, disease-free and overall survival in 385 patients with primary clear cell renal cell carcinoma. We also correlated the LDHA expression with overall survival, at mRNA level, in an independent data set of 170 clear cell renal cell carcinoma cases from The Cancer Genome Atlas databases. Cox proportional hazards models adjusted for the potential clinicopathological factors were used to test for associations between the LDHA expression and both disease-free survival and overall survival.

Results: There is statistically significant positive correlation between LDHA level of expression and tumor size, clinical stage and histological grade. Moreover, LDHA expression shows significantly inverse correlation with both disease-free survival and overall survival in patients with clear cell renal cell carcinoma. Our results are validated by examining LDHA expression, at the mRNA level, in the independent data set of clear cell renal cell carcinoma cases from The Cancer Genome Atlas databases which also shows that higher lactate dehydrogenase A expression is associated with significantly shorter overall survival.

Conclusion: Our results indicate that LDHA up-regulation can be a predictor of poor prognosis in clear cell renal cell carcinoma. Thus, it represents a potential prognostic biomarker that can boost the accuracy of other prognostic models in patients with clear cell renal cell carcinoma.
\end{abstract}

Keywords: Lactate dehydrogenase A, Prognosis, Renal cell carcinoma, Personalized medicine, Tumor markers, Proteomics, Pathology, Metastasis

\section{Introduction}

Renal cell carcinoma (RCC) is the most common type of malignant adult kidney tumors, accounting for more than $90 \%$ of all adult renal tumors. The incidence of renal cell carcinoma has been steadily rising in North America over the past decades [1]. About half of RCC patients are

\footnotetext{
* Correspondence: yousefg@smh.ca

${ }^{1}$ The Keenan Research Center in the Li Ka Shing Knowledge Institute, St. Michael's Hospital, Toronto M5B 1 W8, Canada

${ }^{2}$ Department of Laboratory Medicine, St. Michael's Hospital, Toronto M5B 1 W8, Canada

Full list of author information is available at the end of the article
}

diagnosed with a localized tumor while $25 \%$ of patients present with locally invasive tumors, and the remaining $25 \%$ present with metastasis at the time of diagnosis, mainly to the bone and lung [2]. There are several histological sub-types of renal cell carcinoma which differ in incidence, biological behaviour and the potential metastasis. Approximately $75 \%$ of RCC patients have the clear cell renal cell carcinoma subtype (ccRCC) [3].

Over $90 \%$ of cancer associated mortality in RCC is due to metastasis, which is a complex process starting with

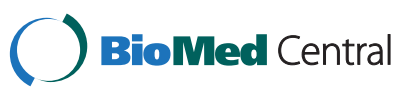

(c) 2014 Girgis et al.; licensee BioMed Central Ltd. This is an Open Access article distributed under the terms of the Creative Commons Attribution License (http://creativecommons.org/licenses/by/4.0), which permits unrestricted use, distribution, and reproduction in any medium, provided the original work is properly credited. The Creative Commons Public Domain Dedication waiver (http://creativecommons.org/publicdomain/zero/1.0/) applies to the data made available in this article, unless otherwise stated. 
local invasion, followed by intravasation, survival in the circulation, extravasation, initiation and maintenance of micro metastasis at distant sites, and finally, vascularisation of new tumor. The prognosis of RCC is quite variable. A number of prognostic models have been proposed [4], most of them are based only on clinical parameters but they all lack accuracy. In the new era of personalized medicine, better performing prognostic models are urgently required to better stratify patients for clinical trials and to provide more accurate clinical information that can significantly enhance decision making for patient management [5,6]. Improving the accuracy and discriminatory power of these models is likely to require identification and incorporation of multiple molecular markers [7]. A number of molecular markers for kidney cancer prognosis have been suggested but none of them have gained acceptance for clinical practice so far [8-11].

A number of genetic alterations and consequent metabolic changes are involved in metastatic progression of cancer [12]. The lactate dehydrogenase A (LDHA) protein, a target gene of c-Myc and hypoxia-inducible factor (HIF-1) located on the short $\mathrm{p}$ arm of chromosome 11 (11p15.4), is considered to be a critical branch point in metabolism of tumor cells [13-15]. Previous studies showed an association between up-regulation of LDHA and increased proliferation of tumor cells, particularly those with high malignant potential, and tumors that are poorly differentiated [16]. In oesophageal squamous cell carcinoma, knockdown of the expression of LDHA inhibited cell growth and cell migration in vitro as well as tumorigenesis in vivo [17]. It was also shown that knockdown of LDHA suppresses tumor growth and metastasis of human hepatocellular carcinoma [18]. On the other hand, inhibition of LDHA activity enhances mitochondrial respiration and decreases mitochondrial membrane potential which both compromises the ability of the tumor cells to proliferate under hypoxia and lead to apoptosis [19]. As the tumorigenicity of the LDHA-deficient cells was severely diminished, LDHA plays a key role in tumor maintenance [20].

Using quantitative proteomic analysis, we have recently identified a number of proteins, including LDHA, that are deregulated in metastatic compared to primary RCC [21], and showed that they are involved in pathways related to tumor progression and metastasis [22].

In the current study, we investigated the expression of LDHA in primary ccRCC and compared its expression with multiple clinicopathologic parameters including clinical stage, histological grade and tumor size. In addition, we examined the relationship between LDHA expression and patients' survival. We show that high expression of LDHA can be considered as a predictor of poor prognosis in patients with ccRCC.

\section{Materials and methods}

\section{Patient tissues and tissue micro array construction}

Tissue microarrays (TMAs) were built using 385 tumor specimens from $10 \%$ buffered formalin fixed paraffin -embedded (FFPE) tissue blocks obtained with Research Ethics Board approval from the surgical pathology archives of St. Michael's Hospital, University Health Network, and London Health Sciences Center between 2001-2009. All cases were primary clear cell renal cell carcinoma (ccRCC) and were reviewed by a pathologist. All new recognized entities including clear cell papillary, translocation carcinomas etc. were excluded from the analysis. Distribution of the numerical variables of the study population is shown in Table 1. Disease-free survival was defined as the time between the first surgical resection and disease recurrence. Overall survival was defined as the time between the first surgery for primary RCC and death for any reason. Diagnosis and selection of pure tumor areas were performed by a pathologist. Tumor grading was done according to the original Fuhrman grading system [23]. The two cores were obtained from two different blocks to account for tumor heterogeneity. Areas of necrosis were avoided. For 85 specimens, matched normal tissues from the same patient were available. Each specimen was represented by two $1 \mathrm{~mm}$ cores. Paraffin sections of the TMA were cut for immunohistochemistry (IHC) in $4 \mu \mathrm{m}$ thickness.

\section{Immunohistochemical staining and scoring}

Tumors were scored positive for LDHA if tumor cells showed definite nuclear and/or membranous staining and negative if tumor nuclei and cell membrane had no immunoreactivity. A combination of a proportion score and an intensity score was used to assess LDHA immunostaining: the proportion score (proportion of positive tumor cells on the studied section) was: 0: none, 1: 1-24\%, 2: $25-49 \%, 3: 50-74,4: \geq 75 \%$. The intensity score (intensity of staining by tumor cells) was: 0: none, 1 : weak, 2 : moderate, 3: strong. Three cases were used as calibrators to define intensity. A total score was obtained by the combining both scores. Cores were evaluated independently by two pathologists and controversial cases were assigned a consensus score after discussion. Representative micrographs of immunostaining are shown in Figure 1.

Two cores were evaluated for each patient, and the arithmetic average score was reported. Immunohistochemical staining was performed on paraffin-embedded specimen using a semi automated Discovery autostainer (Ventana Medical System, Inc., Tucson, AZ) and ChromoMapDAB multimer kit (Ventana). Tissues were exposed to the mouse monoclonal LDHA primary antibody (Abgent, Inc., Dan Diego, A; clone: 3H2; dilution 1:25) for 2 hours at room temperature, followed by 16 - minutes using pre-diluted Ultra Map Rabbit horseradish peroxidase 
Table 1 Distribution of numerical variables of the study population

\begin{tabular}{|c|c|c|c|c|c|}
\hline \multirow[b]{2}{*}{ Variable } & \multirow[b]{2}{*}{ Mean \pm S.E. ${ }^{a}$} & \multirow[b]{2}{*}{ Range } & \multicolumn{3}{|c|}{ Percentile } \\
\hline & & & $25^{\text {th }}$ & $50^{\text {th }}$ (Median) & $75^{\text {th }}$ \\
\hline Tumor size $(\mathrm{cm})$ & $5.9 \pm 0.2$ & $0.7-19.5$ & 3.2 & 5.0 & 8.0 \\
\hline DFS (months) & $50.0 \pm 2.0$ & $0.0-204.0$ & 13.0 & 48.0 & 80.5 \\
\hline OS (months) & $57.1 \pm 1.9$ & $0.0-216.0$ & 24.00 & 61.0 & 86.0 \\
\hline
\end{tabular}

astandard error of the mean.

(Ventana). Antigen retrieval was performed using standard CC1. Replacement of the primary antibody with phosphate-buffered saline served as a negative control. In order to examine the effect of tumor heterogeneity on LDHA staining pattern, we compared its expression between the two cores of the same specimen. There was an $86 \%$ concordance in the expression levels of the two cores. Moreover, we compared expression between the TMA cores and whole slide staining in 20 cases. The degree of concordance was $90 \%$.

\section{Statistical analysis}

Fuhrman grading was assessed as that indicated in the pathology report of the case. Pathological staging was used for each patient. We performed Jonckheere-Terpstra Test in order to investigate the relationships between continuous variables and the three levels of the LDHA expression. Pearson Chi-square test or Fisher's Exact Test were used to evaluate the associations between LDHA expression status and several clinicopathological variables. Univariate and Multivariate Cox proportional hazard regression analyses were used to estimate the prognostic significance of the LDHA in ccRCC patients. The Multivariate model was adjusted for patients' sex, tumor size, histological grade and tumor stage. Cases with incomplete clinical information were excluded from related analysis. $P$ values were calculated by the test for trend approach. Kaplan-Meier curves were also constructed in order to plot the percentage probability of patients' DFS and OS, after their classification to LDHA-low, moderate or high expression.

\section{Bioinformatics analysis}

Level 3 gene expression data (normalized gene expression data derived from the Cancer Genome Characterization Centre at the University of North Carolina using the Illumina HiSeq RNA Sequencing platform) for LDHA in ccRCC and normal kidney and overall survival data were
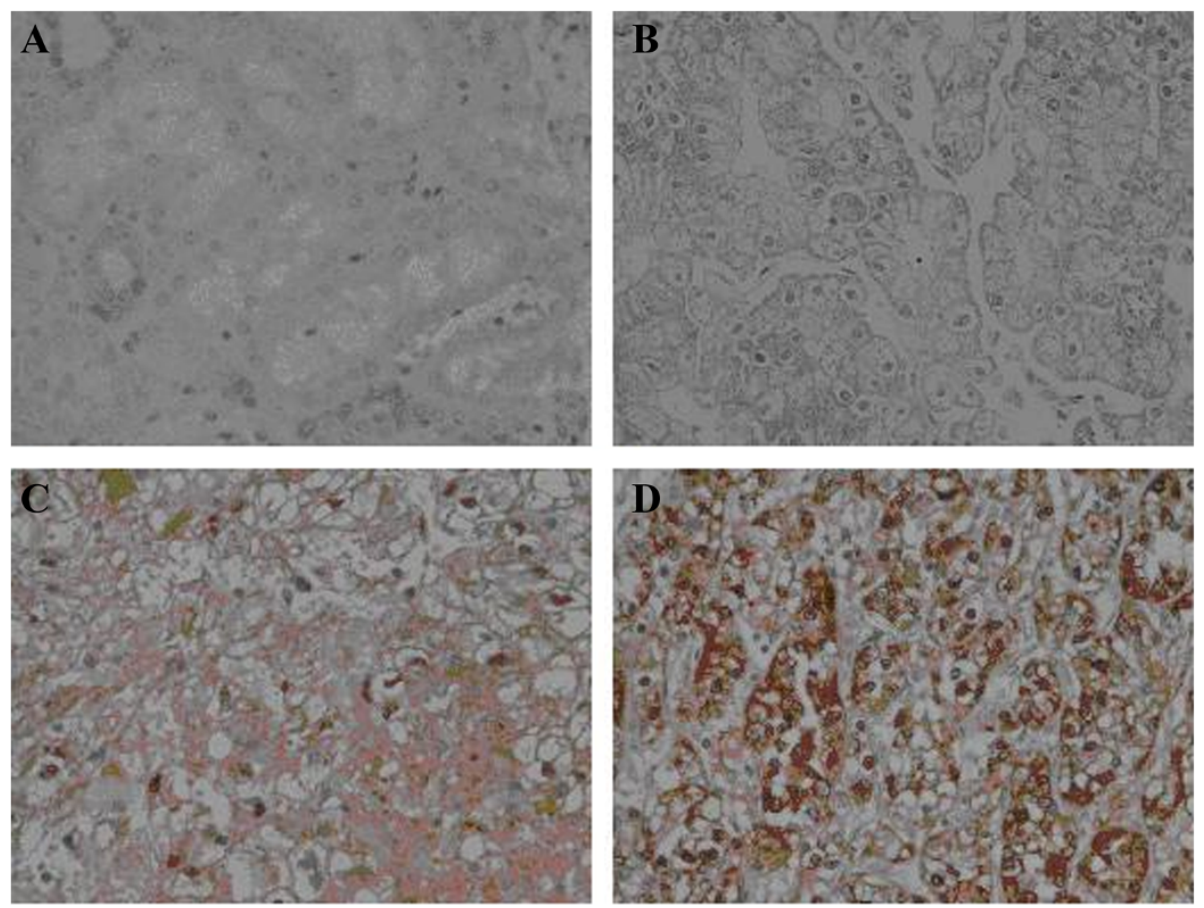

Figure 1 Representative photomicrographs showing the expression of LDHA protein by immunohistochemistry. (A) Normal kidney proximal tubular epithelium, (B) weak, (C) moderate, and (D) strong staining Clear Cell Renal Cell Carcinoma (all figures are original magnification X400). 
obtained from The Cancer Genome Atlas (TCGA), available through the cBio Cancer Genomics Portal (http:// www.cbioportal.org/public-portal). Tumors were selected with at least $80 \%$ tumor nuclei concentration and at most 5\% necrosis generating a dataset of 170 cases. The X-tile algorithm was used to generate a prognostic optimal cutoff point to dichotomize LDHA mRNA expression as LDHA high expression and LDHA low expression using a Monte Carlo ( $p$ value $<0.05$ ). TCGA data types, platforms, and methods have been described previously. Twofold LDHA mRNA expression difference cut offs were generated for tumor versus geometric mean of normal kidney.

\section{mi RNA target prediction analysis}

Target prediction analysis were performed using the target scan software (http://www.targetscan.org/).

\section{miRNA expression validation}

To further validate our data we examined LDHA expression by qRT-PCR analysis using gene specific probes on 40 cases of primary ccRCC. PCR was performed according to the protocol suggested by the manufacturer.

\section{Results}

LDHA expression is up-regulated in primary ccRCC compared to normal kidney tissue

We compared the expression of LDHA protein between 85 matched normal/cancer specimens from the same patients. There was very weak/no expression of the LDHA protein in all normal proximal tubules of the kidney cortex (which is accepted in the literature as the structure of origin of ccRCC and is considered to be the appropriate normal control) [24]. ccRCC tissue from the same patients showed LDHA expression of variable frequency and intensity as described below. This is in keeping with recent literature and our previous data showing up-regulation of LDHA in RCC compared to normal tissue $[25,26]$.

In order to validate our results, we evaluated LDHA expression, at the mRNA level; in an independent set of 170 cases of ccRCC (data are available from the TCGA database). In accordance with the protein expression, we observed increased LDHA mRNA levels in kidney cancer compared with normal renal cortex in 162 of 170 patients (95\%). These results further confirm the potential prognostic utility of LHDA in this independent data set.

\section{The prognostic significance of LDHA protein in ccRCC}

The association between LDHA expression levels and other clinicopathological variables are summarized in (Table 2). There was a statistically significant association between the LDHA levels of expression and tumor size; with larger tumors showing significantly higher proportion of LDHA expression $(p<0.001)$ (Table 2 and Figure 2). There was also a stepwise increase in LDHA
Table 2 Associations between LDHA expression levels and clinicopathological variables of patients

\begin{tabular}{|c|c|c|c|c|c|}
\hline \multirow[t]{2}{*}{ Variable } & \multirow[t]{2}{*}{ Total } & \multicolumn{2}{|c|}{ No. of patients (\%) } & \multirow{2}{*}{$\begin{array}{l}\text { LDHA- } \\
\text { High } \\
\text { expression }\end{array}$} & \multirow[t]{2}{*}{$P$-value ${ }^{a}$} \\
\hline & & $\begin{array}{l}\text { LDHA- } \\
\text { Low } \\
\text { expression }\end{array}$ & $\begin{array}{l}\text { LDHA- } \\
\text { Moderate } \\
\text { expression }\end{array}$ & & \\
\hline
\end{tabular}

\begin{tabular}{cccccc}
\hline $\begin{array}{c}\text { Tumor size } \\
<5\end{array}$ & 196 & $35(17.9 \%)$ & $130(66.3 \%)$ & $31(15.8 \%)$ & \\
$\geq 5$ & 149 & $23(15.4 \%)$ & $70(47.0 \%)$ & $56(37.6 \%)$ & $<0.001$ \\
X & 40 & & & & \\
Grade & & & & & \\
I & 31 & $5(16.1 \%)$ & $24(77.4 \%)$ & $2(6.5 \%)$ & \\
II & 180 & $29(16.1 \%)$ & $114(63.3 \%)$ & $37(20.6 \%)$ & \\
II & 103 & $18(17.5 \%)$ & $50(48.5 \%)$ & $35(34.0 \%)$ & $<0.001$ \\
IV & 22 & $1(4.5 \%)$ & $9(40.9 \%)$ & $12(54.5 \%)$ & \\
X & 49 & & & & \\
Stage & & & & & \\
I & 190 & $35(18.4 \%)$ & $124(65.3 \%)$ & $31(16.3 \%)$ & $<0.001$ \\
II & 35 & $8(22.9 \%)$ & $18(51.4 \%)$ & $9(25.7 \%)$ & \\
III & 49 & $8(16.3 \%)$ & $27(55.1 \%)$ & $14(28.6 \%)$ & \\
IV & 33 & $0(0 \%))$ & $7(21.2 \%)$ & $26(78.8 \%)$ & \\
X & 78 & & & & \\
Sex & & & & & \\
Female & 120 & $24(20.0 \%)$ & $75(62.5 \%)$ & $21(17.5 \%)$ & 0.051 \\
Male & 230 & $35(15.2 \%)$ & $128(55.7 \%)$ & $67(29.1 \%)$ & \\
X & 35 & & & & \\
\hline
\end{tabular}

Calculated using Pearson Chi-Square test.

$\mathrm{x}$ : Status is unknown.

protein expression that is positively associated with tumor grade $(p<0.001)$ (Table 2$)$. While $93 \%$ of grade I tumors expressed low to moderate levels of LDHA and LDHA high expression was only found in $6.5 \%$ of cases, in grade IV tumors $46 \%$ of cases showed low to moderate expression compared to 55\% with high levels of expression. Moreover, there was a statistically significant stepwise increase in LDHA-high expression and tumor stage. While only $16 \%$ of stage I tumors showed high expression, the majority (79\%) of stage IV tumors demonstrated LDHA-high expression $(p<0.001)$ (Table 2).

The correlation of LDHA expression to the diseasefree survival and overall survival were calculated using univariate and multivariate analyses (Table 3). Specimens were classified according to their LDHA level of expression as low, moderate, or high. Univariate analysis showed that patients who had tumors with high LDHA expression, exhibited significantly shorter disease-free survival than those who had tumors with low or moderate LDHA expression with a10 fold higher chances of relapse (hazard ratio $(\mathrm{HR})=10.23 ; p<0.001)$. Also, LDHA higher expression was associated with significant shorter overall 


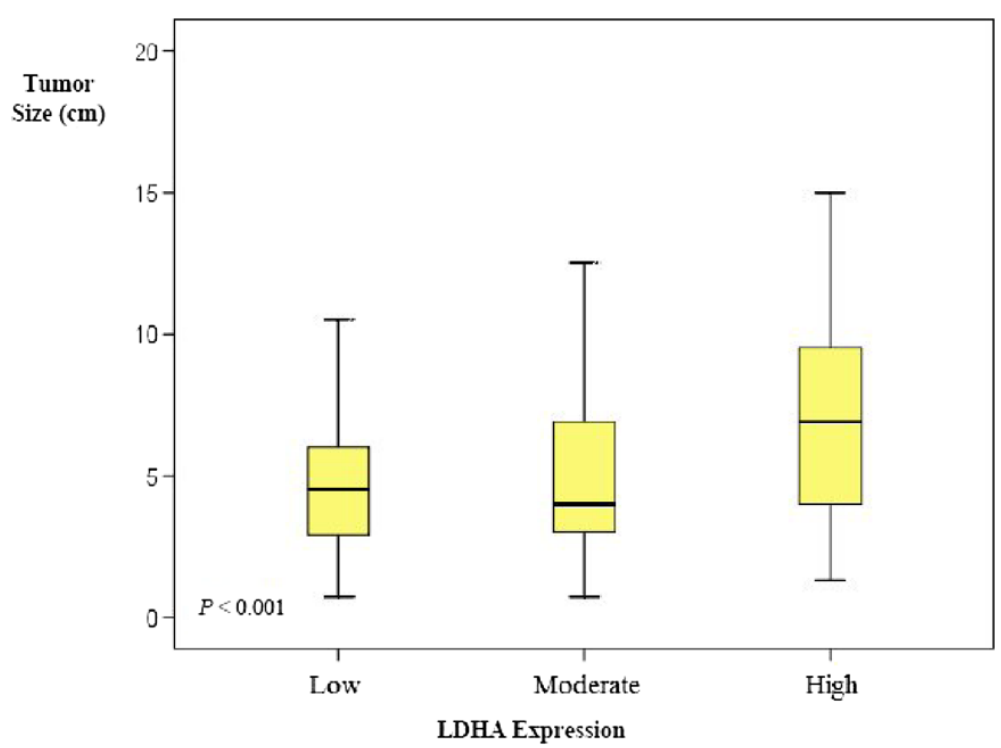

Figure 2 Box plot representing LDHA expression levels in relation to tumor size. There is a statistically significant association between the LDHA level of expression and tumor size; with larger tumors showing significantly higher proportion of LDHA expression $(p<0.001)$. Bold lines represent the median value (50th percentile) for each patient cohort. $P$ value is calculated by "Jonckheere-Terpstra Test".

survival with 4 times chances of death. (HR $=4.04 ; p=$ 0.026). In the multivariate analysis, LDHA continued to show significant correlation between high expression and shorter disease-free survival after controlling for other variables $(\mathrm{HR}=4.3 ; p=0.007)$. There was also a trend of positive association between high LDHA expression and poor overall survival, although this did not reach statistical significance after controlling for other variables $(\mathrm{HR}=3.46, p=0.1)$.

Kaplan-Meier survival curves indicated that patients in the high LDHA expression arm have a statistically significant decrease in disease-free survival $(p=0.001)$

Table 3 Univariate and multivariate analyses of LDHA expression and patients' survival

\begin{tabular}{|c|c|c|c|c|c|c|}
\hline \multirow[t]{2}{*}{ Variable } & \multicolumn{3}{|c|}{ Disease-free survival } & \multicolumn{3}{|c|}{ Overall survival } \\
\hline & $\mathrm{HR}^{\mathrm{a}}$ & $95 \% \mathrm{Cl}^{\mathrm{b}}$ & $P$-value & $\mathrm{HR}^{\mathrm{a}}$ & $95 \% \mathrm{Cl}^{\mathrm{b}}$ & $P$-value \\
\hline \multicolumn{7}{|c|}{ Univariate analysis $(\mathrm{N}=338)$} \\
\hline \multicolumn{7}{|l|}{ LDHA expression } \\
\hline Low & 1.00 & & & 1.00 & & \\
\hline Moderate & 1.12 & $0.37-3.39$ & 0.83 & 0.97 & $0.26-3.59$ & 0.96 \\
\hline High & 10.23 & $3.68-28.41$ & $<0.001$ & 4.04 & $1.18-13.85$ & 0.026 \\
\hline Stage (nominal) & 7.10 & $4.29-11.75$ & $<0.001$ & 3.57 & $1.75-7.31$ & $<0.001$ \\
\hline Histological grade(nominal) & 4.27 & $2.65-6.88$ & $<0.001$ & 3.78 & $1.92-7.44$ & $<0.001$ \\
\hline \multicolumn{7}{|c|}{ Multivariate analysis ${ }^{c}(\mathrm{~N}=279)$} \\
\hline \multicolumn{7}{|l|}{ LDHA expression } \\
\hline Low & 1.00 & & & 1.00 & & \\
\hline Moderate & 0.90 & $0.29-2.78$ & 0.85 & 0.92 & $0.19-4.51$ & 0.92 \\
\hline High & 4.30 & $1.48-12.53$ & 0.007 & 3.46 & $0.73-16.36$ & 0.12 \\
\hline Tumor size (nominal) & 1.70 & $0.86-3.37$ & 0.13 & 0.69 & $0.26-1.87$ & 0.46 \\
\hline Stage (nominal) & 3.35 & $1.89-5.94$ & $<0.001$ & 1.86 & $0.78-4.41$ & 0.16 \\
\hline Histological grade(nominal) & 2.11 & $1.13-3.96$ & 0.02 & 3.17 & $1.17-8.60$ & 0.02 \\
\hline Sex & 0.70 & $0.40-1.24$ & 0.23 & 1.14 & $0.44-2.95$ & 0.78 \\
\hline
\end{tabular}

a Hazard ratio, estimated from Cox proportional hazard regression model.

${ }^{\mathrm{b}}$ Confidence interval of the estimated HR.

${ }^{\mathrm{C}}$ Multivariate models were adjusted for tumor size, histological grade, sex and tumor stage. 
compared to those in the low LDHA expression arm (Figure 3). Also, high LDHA expression was associated with significant decrease in overall survival compared to low or moderate expression $(p<0.001)$ (Figure 4$)$. Taken together, these data show that LDHA expression can be used as a strong independent predictor of poor prognosis in patients with ccRCC.

\section{Prognostic value of LDHA at the mRNA level}

We also examined the prognostic significance of LDHA expression in ccRCC at the mRNA level using the TCGA dataset. On the basis of LDHA expression, patients were classified as LDHA high expression and LDHA low expression using an optimized cut-off value of the $87^{\text {th }}$ percentile (see Materials and Methods), and the resulting groups included 22 LDHA high expression patients and 147 low expression patients. Similar to the results of IHC analysis, we detected a statistically significant reduction in overall survival with higher LDHA mRNA expression $(p=0.04)$ (Figure 5).

\section{LDHA mRNA expression validation}

We further validated our results using another independent set of 40 cases of primary ccRCC at mRNA level. Patients with higher LDHA expression were associated with a significantly worse prognosis compared to those who are LDHA negative $(p=0.023)$. (Data are not shown).

\section{Mechanisms of LDHA up-regulation in ccRCC}

To explore potential mechanisms of LDHA activation, we have recently conducted genome-wide copy number profiling of ccRCC specimens and have observed whole chr11 gain in 5\% of specimens [27]. To validate our results, we quarried LDHA copy number gain on the ccRCC data set from TCGA. A total of 170 ccRCCs were analyzed (see Materials and Methods). LDHA copy number gain was observed in 9 of 170 specimens (5\%). These findings indicate that copy number gain could be responsible, at least in part, for LDHA up-regulation in ccRCC.

Also, in order to explore other mechanisms that can results in the differential expression of LDHA in renal cell carcinoma, we performed target prediction analysis using TargetScanHuman 6.2 (http://www.targetscan.org/). Our analysis showed that LDHA is a predicted target of miR-449a, miR-449b, miR-34a and miR-34c-5p.

We next compared the expression of LDHA and its targeting miRNAs between RCC and normal kidney tissues. We observed an inverse correlation between LHDA and miR-449a and miR-449b, where the levels of these two miRNAs were down-regulated in primary ccRCC compared to normal kidney [28,29] while LDHA was up-regulated. Taken together, these data point indicate that these miRNAs can be responsible, at least in part, for the LDHA up-regulation in ccRCC.

In order to further explore potential mechanisms that can be responsible for LHDA up-regulation in aggressive RCC correlated its expression between primary and metastatic RCC. We identified an inverse correlation between miR-34a and LDHA between primary and metastatic ccRCC, indicating that miR34a down-regulation in metastatic disease [28] can release its inhibitory effect on LDHA with subsequent up-regulation.

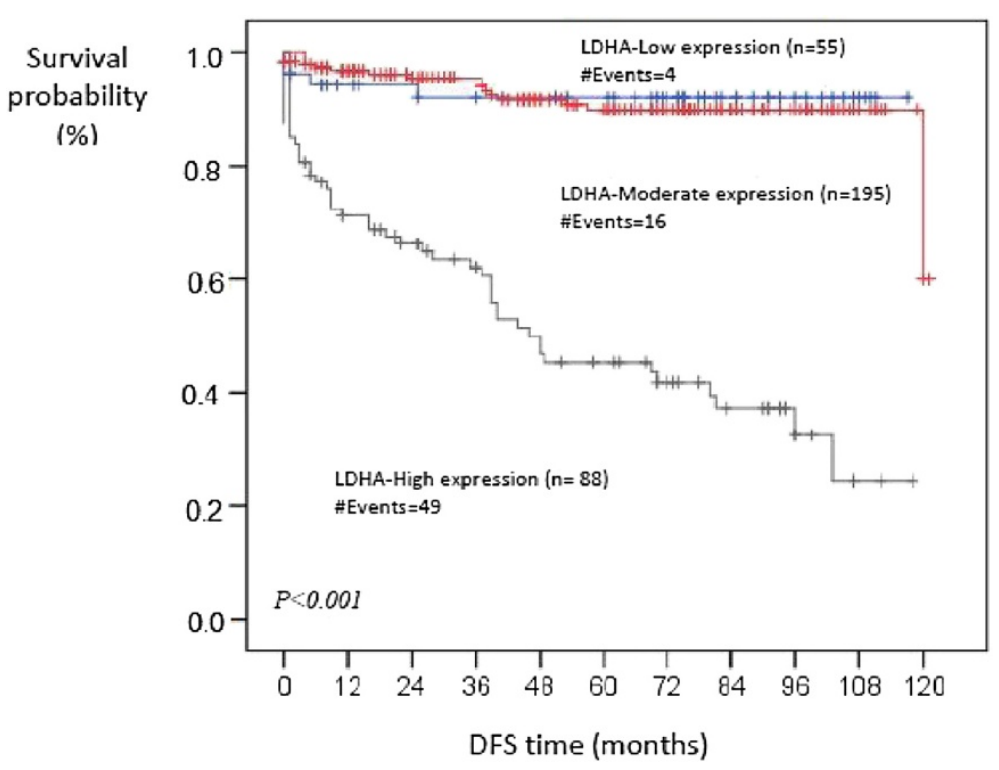

Figure 3 Kaplan-Meier curve for DFS of patients with low, moderate and high expression of LDHA protein. Patients in the high LDHA expression arm have a statistically significant decrease in disease-free survival $(p=0.001)$ compared to those in the low LDHA expression arm. 


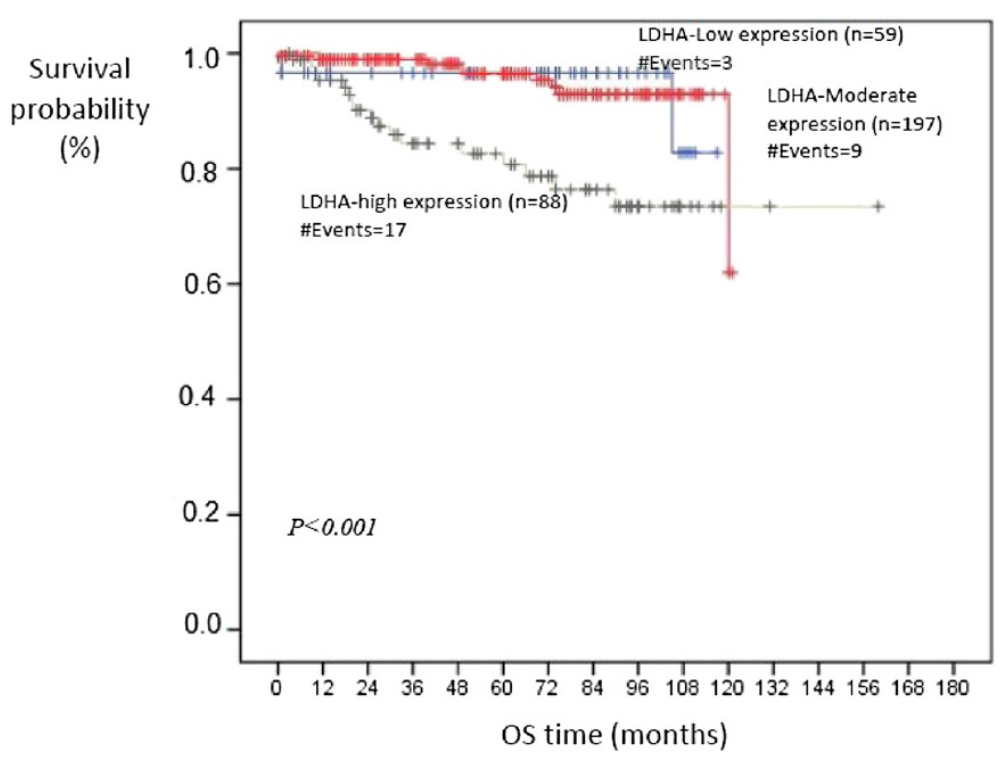

Figure 4 Kaplan-Meier curve for OS of patients with low, moderate and high expression of LDHA protein. Patients in the high LDHA arm have a statistically significant decrease in overall survival $(p<0.001)$ compared to those in the low and moderate LDHA expression arm.

\section{Discussion}

Clear cell Renal Cell Carcinoma is the most common subtype of renal cell carcinoma with increasing incidence, high metastatic potential and high mortality rate. It would be useful to understand the process of metastasis in ccRCC and to discover novel parameters that impact the risk of recurrence and response to specific therapies.

Earlier studies showed that cancer cells preferentially use glycolysis to produce adenosine triphosphate, even in the presence of normal levels of oxygen. The abnormalities that occur in energy metabolism of cells are a fundamental aspect of cancer (Warburg effect phenomenon) [30-32]. It has been established that in Fumarate Hydratase (FH)-deficient kidney cancer, there is impaired oxidative phosphorylation with metabolic shift to aerobic glycolysis to generate ATP required for the increased energy demand of the rapidly proliferating tumor cells [33]. This process requires the uptake of glucose and the generation of lactate through LDHA. Increased lactate production eventually leads to glutamine dependent reductive carboxylation, rather than oxidative metabolism. Metabolic changes have also been reported in RCC $[22,34]$. Glutamine is the major source for the increased fatty acid synthesis required for rapid proliferation of cancer cells. LDHA plays a key role in aerobic glycolysis as it is involved in the metabolism of the two major nutrients glucose and glutamine. Accordingly, LDHA is critical in maintenance and progression of tumors. Previous studies confirmed the significant higher expression of LDHA in RCC compared to the corresponding normal kidney tissue

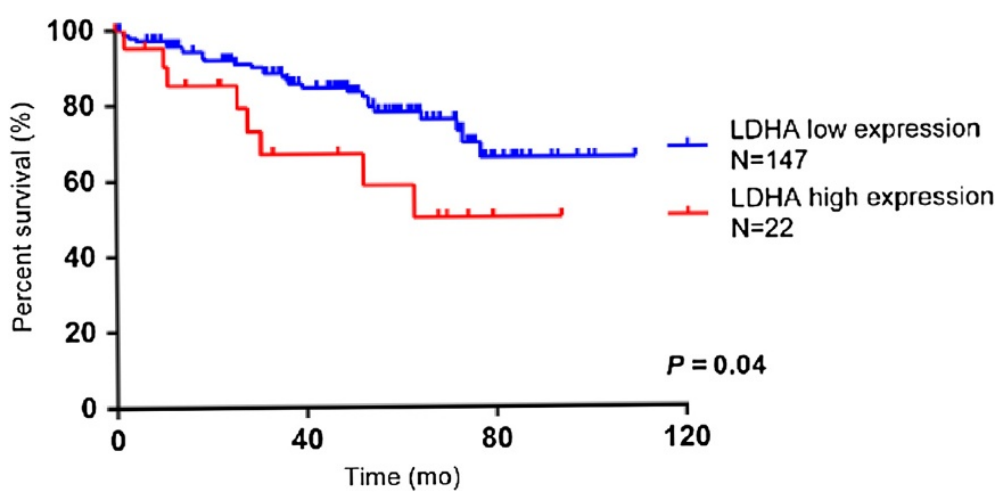

Figure 5 Kaplan-Meier survival curve for overall survival of patients with low and high expression of LDHA. mRNA data was obtained from the Cancer Genome Atlas (TCGA) dataset. On the basis of LDHA expression, patients are classified as LDHA high expression and LDHA low expression. Similar to the results of imunohistochemical analysis, the curve indicates a statistically significant reduction in overall survival with higher LDHA mRNA expression ( $p=0.04)$. 
$[35,36]$. On the other hand, it was also proven that LDHA inhibition results in increasing apoptosis of the tumor cells in FH-deficient kidney cancer and is considered in therapeutic strategy for patients with kidney cancer [37-39].

The correlation between LDHA expression and the tumor grade should be interpreted with caution because the current system of kidney cancer grading relies on assigning the grade of the tumor according to the area of the highest grading not according to the grading of the majority of the tumor.

Our results demonstrate the potential prognostic value of LDHA in ccRCC by detecting its significantly higher expression in patients with advanced clinical stage and histological grade. We also found that LDHA level of expression in primary RCC is directly proportional with the tumor size and is associated with significant decrease of both disease free survival and overall survival. We validated our results at the mRNA level using an independent data set from TCGA databases. The results confirm the prognostic utility of LDHA in ccRCC. Our results are in agreement with previous clinical findings. A commonly used model to predict risk in metastatic RCC, defined by Motzerat Memorial Sloan-Kettering, includes high serum LDH as one of the prognostic factors [40]. This model has been validated [41]. Another recent study showed that LDH and performance status outperformed several other variables that are part of prognostic models in patients with brain metastases [42].

We have also shown that copy number aberration was only observed in 5\% of ccRCC cases. This is consistent with the recent data published by our group and others $[7,27,43,44]$. This was validated by our recent study and others.

At present, there are few proposed molecular prognostic markers described in kidney cancer [45]. They include CD31, EDNRB and TSPAN7 [46], carbonic anhydrase 9 [47], factor inhibiting hypoxia- inducible factor (FIH) [48], VHL protein alterations [49], miR-21 expression [8], microvascular density [50], and the chromatin remodelling gene ARID1A [51]. Integration of LDHA appears to be a useful additional way to identify poor prognosis in kidney cancer patients.

In conclusion, we provide strong evidence for the potential utility of LDHA as a prognostic marker for both disease free and overall survival in RCC. Our data was validated in two independent sets, both in the mRNA and protein levels of expression. Integration of LDHA expression levels in multiparametric model might enhance its performance. In addition to be a prognostic marker, our data paves the road for investigating LDHA as a potential therapeutic target in RCC.

\section{Abbreviations}

LDHA: Lactate dehydrogenase A; ccRCC: Clear cell renal cell carcinoma.

\section{Competing interests}

The authors declare that they have no competing interests.

\section{Authors' contributions}

HG interpreted the $\mathrm{HC}$ results, OM, NMAW, FR performed the immunohistochemistry, AS performed the statistical analysis, ALS, MG, ERF, $A E, S A$ constructed the tissue microarray and obtained the clinical parameters and survival information, AHAG performed the in silico analysis, GAB, MASJ, KWMS, and GMY conceived of the study, and participated in its design and coordination. All authors contributed to manuscript writing and read and approved the final manuscript.

\section{Acknowledgment}

This work was supported by grants from the Canadian Institute of Health Research, Kidney Foundation of Canada, the Kidney Cancer Research Network of Canada, and Prostate Cancer Canada.

\section{Author details}

${ }^{1}$ The Keenan Research Center in the Li Ka Shing Knowledge Institute, St. Michael's Hospital, Toronto M5B 1 W8, Canada. ${ }^{2}$ Department of Laboratory Medicine, St. Michael's Hospital, Toronto M5B 1 W8, Canada. ${ }^{3}$ Department of Chemistry and Centre for Research in Mass Spectrometry, York University, 4700 Keele Street, Toronto M3J 1P3, Canada. ${ }^{4}$ Department of Laboratory Medicine and Pathobiology, University of Toronto, Toronto M5S 1A8, Canada. ${ }^{5}$ Department of Biochemistry and Molecular Biology, Faculty of Biology, University of Athens, 15701 Athens, Greece. 'Department of Pathology, London Health Sciences Center and Western University, London N6A 5 W9, Canada. ${ }^{7}$ Division of Medical Oncology and Hematology, Sunnybrook Odette Cancer Center, Toronto, ON M4N 3 M5, Canada. ${ }^{8}$ Division of Urologic Oncology, Princess Margaret Hospital, University Health Network, Toronto, ON M5G 2 M9, Canada. 'Department of Laboratory Medicine, University Health Network, Toronto, Canada.

Received: 20 February 2014 Accepted: 22 April 2014

Published: 5 May 2014

\section{References}

1. Simard EP, Ward EM, Siegel $R$, Jemal A: Cancers with increasing incidence trends in the United States: 1999 through 2008. CA Cancer J Clin 2012, 62:118-124.

2. Siegel $R$, Naishadham D, Jemal A: Cancer statistics, 2012. CA Cancer J Clin 2012, 62:10-29.

3. Cheville JC, Lohse CM, Zincke H, Weaver AL, Blute ML: Comparisons of outcome and prognostic features among histologic subtypes of renal cell carcinoma. Am J Surg Pathol 2003, 27:612-624.

4. Heng DY, Xie W, Regan MM, Harshman LC, Bjarnason GA, Vaishampayan UN, Mackenzie M, Wood L, Donsko F, Tan MH, Rha SY, Agarwal N, Kollmannsberger C, Rini BI, Choueiri TK: External validation and comparison with other models of the International Metastatic Renal-Cell Carcinoma Database Consortium prognostic model: a population-based study. Lancet Oncol 2013, 14:141-148.

5. Heng DY, Xie W, Regan MM, Warren MA, Golshayan AR, Sahi C, Eigl BJ, Ruether JD, Cheng T, North S, Venner P, Knox JJ, Chi KN, Kollmannsberger C, McDermott DF, Oh WK, Atkins MB, Bukowski RM, Rini Bl, Choueiri TK: Prognostic factors for overall survival in patients with metastatic renal cell carcinoma treated with vascular endothelial growth factor-targeted agents: results from a large, multicenter study. J Clin Oncol 2009, 27:5794-5799.

6. Pasic MD, Samaan S, Yousef GM: Genomic medicine: new frontiers and new challenges. Clin Chem 2013, 59:158-167.

7. White NM, Yousef GM: Translating molecular signatures of renal cell carcinoma into clinical practice. J Urol 2011, 186:9-11.

8. Faragalla H, Youssef YM, Scorilas A, Khalil B, White NM, Mejia-Guerrero S, Khella H, Jewett MA, Evans A, Lichner Z, Bjarnason G, Sugar L, Attalah MI, Yousef GM: The clinical utility of miR-21 as a diagnostic and prognostic marker for renal cell carcinoma. J Mol Diagn 2012, 14:385-392.

9. Khella HW, White NM, Faragalla H, Gabril M, Boazak M, Dorian D, Khalil B, Antonios H, Bao TT, Pasic MD, Honey RJ, Stewart R, Pace KT, Bjarnason GA, 
Jewett MA, Yousef GM: Exploring the role of miRNAs in renal cell carcinoma progression and metastasis through bioinformatic and experimental analyses. Tumour Biol 2012, 33:131-140.

10. Tan PH, Cheng L, Rioux-Leclercq N, Merino MJ, Netto G, Reuter VE, Shen SS, Grignon DJ, Montironi R, Egevad L, Srigley JR, Delahunt B, Moch H: Renal tumors: diagnostic and prognostic biomarkers. Am J Surg Patho 2013, 37:1518-1531.

11. Zhang BY, Thompson RH, Lohse CM, Dronca RS, Cheville JC, Kwon ED, Leibovich BC: Carbonic anhydrase IX (CAIX) is not an independent predictor of outcome in patients with clear cell renal cell carcinoma (ccRCC) after long-term follow-up. BJU Int 2013, 111:1046-1053.

12. Yun J, Johnson JL, Hanigan CL, Locasale JW: Interactions between epigenetics and metabolism in cancers. Front Oncol 2012, 2:163.

13. Ashrafian $H, O^{\prime}$ Flaherty $L$, Adam J, Steeples V, Chung YL, East P, Vanharanta S, Lehtonen H, Nye E, Hatipoglu E, Miranda M, Howarth K, Shukla D, Troy H, Griffiths J, Spencer-Dene B, Yusuf M, Volpi E, Maxwell PH, Stamp G, Poulsom R, Pugh CW, Costa B, Bardella C, Di Renzo MF, Kotlikoff Ml, Launonen V, Aaltonen L, El-Bahrawy M, Tomlinson I, et al: Expression profiling in progressive stages of fumarate-hydratase deficiency: the contribution of metabolic changes to tumorigenesis. Cancer Res 2010, 70:9153-9165.

14. Gordan JD, Thompson CB, Simon MC: HIF and c-Myc: sibling rivals for control of cancer cell metabolism and proliferation. Cancer Cell 2007, 12:108-113.

15. Seyfried TN, Shelton LM: Cancer as a metabolic disease. Nutr Metab (Lond) 2010, 7:7.

16. Amann T, Maegdefrau U, Hartmann A, Agaimy A, Marienhagen J, Weiss TS, Stoeltzing O, Warnecke C, Scholmerich J, Oefner PJ, Kreutz M, Bosserhoff AK, Hellerbrand C: GLUT1 expression is increased in hepatocellular carcinoma and promotes tumorigenesis. Am J Pathol 2009, 174:1544-1552.

17. Yao F, Zhao T, Zhong C, Zhu J, Zhao H: LDHA is necessary for the tumorigenicity of esophageal squamous cell carcinoma. Tumour Biol 2013, 34:25-31.

18. Sheng SL, Liu JJ, Dai YH, Sun XG, Xiong XP, Huang G: Knockdown of lactate dehydrogenase A suppresses tumor growth and metastasis of human hepatocellular carcinoma. FEBS J 2012, 279:3898-3910.

19. Le A, Cooper CR, Gouw AM, Dinavahi R, Maitra A, Deck LM, Royer RE, Vander Jagt DL, Semenza GL, Dang CV: Inhibition of lactate dehydrogenase A induces oxidative stress and inhibits tumor progression. Proc Natl Acad Sci U S A 2010, 107:2037-2042.

20. Fantin VR, St-Pierre J, Leder P: Attenuation of LDH-A expression uncovers a link between glycolysis, mitochondrial physiology, and tumor maintenance. Cancer Cell 2006, 9:425-434

21. Masui O, White NM, DeSouza LV, Krakovska O, Matta A, Metias S, Khalil B, Romaschin AD, Honey RJ, Stewart R, Pace K, Bjarnason GA, Siu KW, Yousef GM: Quantitative proteomic analysis in metastatic renal cell carcinoma reveals a unique set of proteins with potential prognostic significance. Mol Cell Proteomics 2013, 12:132-144.

22. White NM, Newsted DW, Masui O, Romaschin AD, Siu KW, Yousef GM: Identification and validation of dysregulated metabolic pathways in metastatic renal cell carcinoma. Tumour Biol 2013, 35:1833-46.

23. Fuhrman SA, Lasky LC, Limas C: Prognostic significance of morphologic parameters in renal cell carcinoma. Am J Surg Pathol 1982, 6:655-663.

24. Pavlovich CP, Schmidt LS: Searching for the hereditary causes of renal-cell carcinoma. Nat Rev Cancer 2004, 4:381-393.

25. Singer K, Kastenberger M, Gottfried E, Hammerschmied CG, Buttner M, Aigner M, Seliger B, Walter B, Schlosser H, Hartmann A, Andreesen R, Mackensen A, Kreutz M: Warburg phenotype in renal cell carcinoma: high expression of glucose-transporter 1 (GLUT-1) correlates with low CD8(+) T-cell infiltration in the tumor. Int J Cancer 2011, 128:2085-2095.

26. Siu KW, DeSouza LV, Scorilas A, Romaschin AD, Honey RJ, Stewart R, Pace K, Youssef $Y$, Chow TF, Yousef GM: Differential protein expressions in renal cell carcinoma: new biomarker discovery by mass spectrometry. J Proteome Res 2009, 8:3797-3807.

27. Girgis AH, lakovlev W, Beheshti B, Bayani J, Squire JA, Bui A, Mankaruos M, Youssef $Y$, Khalil B, Khella H, Pasic M, Yousef GM: Multilevel whole-genome analysis reveals candidate biomarkers in clear cell renal cell carcinoma. Cancer Res 2012, 72:5273-5284.

28. White NM, Bao TT, Grigull J, Youssef YM, Girgis A, Diamandis M, Fatoohi E, Metias M, Honey RJ, Stewart R, Pace KT, Bjarnason GA, Yousef GM: miRNA profiling for clear cell renal cell carcinoma: biomarker discovery and identification of potential controls and consequences of miRNA dysregulation. J Urol 2011, 186:1077-1083.

29. Chow TF, Youssef YM, Lianidou E, Romaschin AD, Honey RJ, Stewart R, Pace KT, Yousef GM: Differential expression profiling of microRNAs and their potential involvement in renal cell carcinoma pathogenesis. Clin Biochem 2010, 43:150-158.

30. Gatenby RA, Gillies RJ: Why do cancers have high aerobic glycolysis? Nat Rev Cancer 2004, 4:891-899.

31. Garber K: Energy deregulation: licensing tumors to grow. Science 2006 312:1158-1159.

32. Garland J: Energy management - a critical role in cancer induction? Crit Rev Oncol Hematol 2013, 88:198-217.

33. Yang $Y$, Valera VA, Padilla-Nash HM, Sourbier C, Vocke CD, Vira MA Abu-Asab MS, Bratslavsky G, Tsokos M, Merino MJ, Pinto PA, Srinivasan R, Ried T, Neckers L, Linehan WM: UOK 262 cell line, fumarate hydratase deficient (FH-/FH-) hereditary leiomyomatosis renal cell carcinoma: in vitro and in vivo model of an aberrant energy metabolic pathway in human cancer. Cancer Genet Cytogenet 2010, 196:45-55.

34. Romaschin AD, Youssef Y, Chow TF, Siu KW, DeSouza LV, Honey RJ, Stewart R, Pace KT, Yousef GM: Exploring the pathogenesis of renal cell carcinoma: pathway and bioinformatics analysis of dysregulated genes and proteins. Biol Chem 2009, 390:125-135.

35. Linehan WM, Rouault TA: Molecular pathways: Fumarate hydratasedeficient kidney cancer-targeting the Warburg effect in cancer. Clin Cancer Res 2013, 19:3345-3352.

36. Serganova I, Rizwan A, Ni X, Thakur SB, Vider J, Russell J, Blasberg R, Koutcher JA: Metabolic imaging: a link between lactate dehydrogenase A, lactate, and tumor phenotype. Clin Cancer Res 2011, 17:6250-6261.

37. Xie H, Valera VA, Merino MJ, Amato AM, Signoretti S, Linehan WM, Sukhatme VP, Seth P: LDH-A inhibition, a therapeutic strategy for treatment of hereditary leiomyomatosis and renal cell cancer. Mol Cancer Ther 2009, 8:626-635.

38. Pelicano $H$, Martin DS, Xu RH, Huang P: Glycolysis inhibition for anticancer treatment. Oncogene 2006, 25:4633-4646.

39. Xu RH, Pelicano H, Zhou Y, Carew JS, Feng L, Bhalla KN, Keatin MJ, Huang P: Inhibition of glycolysis in cancer cells: a novel strategy to overcome drug resistance associated with mitochondrial respiratory defect and hypoxia. Cancer Res 2005, 65:613-621.

40. Motzer RJ, Mazumdar M, Bacik J, Berg W, Amsterdam A, Ferrara J: Survival and prognostic stratification of 670 patients with advanced renal cell carcinoma. J Clin Oncol 1999, 17:2530-2540.

41. Mekhail TM, Abou-Jawde RM, Boumerhi G, Malhi S, Wood L, Elson P, Bukowski R: Validation and extension of the Memorial Sloan-Kettering prognostic factors model for survival in patients with previously untreated metastatic renal cell carcinoma. J Clin Oncol 2005 23:832-841

42. Nieder C, Marienhagen K, Dalhaug A, Norum J: Towards improved prognostic scores predicting survival in patients with brain metastases: a pilot study of serum lactate dehydrogenase levels. Scientific World Journal 2012, 2012:609323

43. Cifola I, Spinelli R, Beltrame L, Peano C, Fasoli E, Ferrero S, Bosari S, Signorini S, Rocc F, Pereg R, Proserpio V, Raimondo F, Mocarelli P, Battaglia C: Genome-wide screening of copy number alterations and LOH events in renal cell carcinomas and integration with gene expression profile. Mol Cancer 2008, 7:6

44. Sanjmyatav J, Junker K, Matthes S, Muehr M, Sava D, Sternal M, Wessendorf S, Kreuz M, Gajda M, Wunderlich H, Schwaenen C: Identification of genomic alterations associated with metastasis and cancer specific survival in clear cell renal cell carcinoma. J Urol 2011 186:2078-2083.

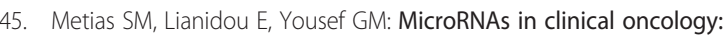
at the crossroads between promises and problems. J Clin Pathol 2009, 62:771-776

46. Wuttig D, Zastrow S, Fussel S, Toma Ml, Meinhardt M, Kalman K, Junker K, Sanjmyatav J, Boll K, Hackermuller J, Rolle A, Grimm MO, Wirth MP: CD31, EDNRB and TSPAN7 are promising prognostic markers in clear-cell renal cell carcinoma revealed by genome-wide expression analyses of primary tumors and metastases. Int J Cancer 2012, 131:E693-E704.

47. Stillebroer AB, Mulders PF, Boerman OC, Oyen WJ, Oosterwijk E: Carbonic anhydrase IX in renal cell carcinoma: implications for prognosis, diagnosis, and therapy. Eur Urol 2010, 58:75-83. 
48. Kroeze SG, Vermaat JS, van Brussel A, van Melick HH, Voest EE, Jonges TG, van Diest PJ, Hinrichs J, Bosch JL, Jans JJ: Expression of nuclear FIH independently predicts overall survival of clear cell renal cell carcinoma patients. Eur J Cancer 2010, 46:3375-3382.

49. Gossage L, Eisen T: Alterations in VHL as potential biomarkers in renal-cell carcinoma. Nat Rev Clin Oncol 2010, 7:277-288.

50. lakovlev W, Gabril M, Dubinski W, Scorilas A, Youssef YM, Faragalla H, Kovacs K, Rotondo F, Metias S, Arsaniousn A, Plotki A, Girgis AH, Streutker C, Yousef GM: Microvascular density as an independent predictor of clinical outcome in renal cell carcinoma: an automated image analysis study. Lab Invest 2012, 92:46-56.

51. Lichner Z, Scorilas A, White NM, Girgis AH, Rotstein L, Wiegand KC, Latif A, Chow C, Huntsman D, Yousef GM: The chromatin remodeling gene ARID1A is a new prognostic marker in clear cell renal cell carcinoma. Am J Pathol 2013, 182:1163-1170.

doi:10.1186/1476-4598-13-101

Cite this article as: Girgis et al:: Lactate Dehydrogenase A is a potential prognostic marker in clear cell renal cell carcinoma. Molecular Cancer 2014 13:101.

\section{Submit your next manuscript to BioMed Central and take full advantage of:}

- Convenient online submission

- Thorough peer review

- No space constraints or color figure charges

- Immediate publication on acceptance

- Inclusion in PubMed, CAS, Scopus and Google Scholar

- Research which is freely available for redistribution 